\title{
Facing the stranger in the mirror: Staged complicities in recent South African performances
}

\author{
Miki Flockemann
}

You are the face I see in the Mirror

A dark shadow.

(Mark Fleishman, Medea 1994)

Should we remember things as a way of learning, or forget them as a way of healing?

(Romesh Gunesekera, in conversation in Aamer Hussein, The Independent, UK 13 April 2002)

By its very nature art-and theatre in particular-poses hard questions, reflects the difficult challenges being grappled with by individuals within historical moments, poses alternatives and celebrates life, optimism and human endeavour even within trying circumstances.

(Mike Van Graan, 'The Art of Democracy,' Cape Times 2009, p. 9)

\section{Introduction}

The staging of complicity has developed into one of the most prevalent trends in recent South Africa theatre. The audience may become aware of their own complicity in injustice, or complicity may feature as a subject to be explored in the play. I will argue that one can identify three broadly defined performance modalities which shape current engagements with complicity. These modalities are identified by the adjectives, 'thick' (as in densely layered, complex, deep), 'reflective' (as in reflecting upon as well as revealing), and 'hard' (in the sense of direct, uncompromising, difficult to penetrate). Rather than signifying distinct categories, these terms are attributed to a cluster of performance dynamics. The term 'thick theatre' is adapted from the key concept of 'thick description' employed by cultural anthropologist Glifford Geertz to emphasize the interpretative function of 'reading' cultural events. The aim here is to compare how the staging of complicity is shaped by the types of aesthetic engagement employed. While 'hard theatre' implicates audiences in complicity, in 'reflective theatre' complicity is explored in terms of the staged experience that is witnessed by the audience. The most challenging exploration of complicity is achieved by the type of 'thick theatre' produced by, for instance, Magnet Theatre and practitioners like Jay Pather, Brett Bailey, Lara FootNewton, and Marthinus Basson. Such practitioners have developed a strong reputation for producing textured work using physical images, and generating 
multiple meanings through innovative stage metaphors which challenge common assumptions. These productions are often collaborative, involving research into local communities, and they question hegemonic knowledge, its production and dissemination. In the process these works often draw on history in order to play with contemporary realities in ways that challenge conventional notions of complicity.

\section{The landscape of complicity}

In responding to the hype and controversy around South Africa's first alien apartheid film District 9 (2009) and its brutally absurd parallels with both the apartheid past and the recent xenophobic violence, Mary Corrigall notes, 'Perhaps any representation of South African life is burdened by its history' (2009a, p. 25). On the other hand, in his discussion of this film Andries du Toit claims that it 'constantly trips us up by making the racist gaze our gaze. It confronts us with our complicity with racism, by making us identify with the perspective of the racist, inviting us to feel the repulsion of the xenophobe-and then pulling the carpet from under our feet.' ${ }^{1}$ This notion of complicity is echoed in responses to Brett Bailey's Blood Diamonds/Terminal produced for the 2009 Grahamstown Festival, in which Grahamstown and its people, present and past, are depicted in three sets of images which Bailey claims 'speak for themselves." Bailey's work is always provocative in the best sense of the term, and an apparently casual observation on his installation points to the possibilities of what I call staging complicity.

Commenting on how he was moved by Bailey's tableaux depicting the town's colonial past and current split along the breadline, Zane Henry remarks: 'Hell, even though I'm from the Flats, I experienced a frisson of white guilt.'3 This remark points to a growing preoccupation with notions of complicity explored in cultural production, which often takes an introspective turn that seeps through familiar race and class divides. As Kelly Oliver suggests, ethical considerations entail a shift from the familiar questions about 'What did they do to us?' to 'What did we do?' (Oliver 2004, p. 85). This preoccupation with complicity is not new, though it has been foregrounded in the wake of recent discussions on how complicity in injustice is bound up with relationships to the 'stranger' in our midst.

The aim here is not only to show how staging complicity has developed into one of the most prevalent trends in recent South African theatre, but also to argue that one can identify three broadly defined performance modalities which shape current engagements with complicity. I will describe these modalities with the adjectives, 'Thick' (as in densely layered, complex, deep), 'Reflective' (as in reflecting upon as well as revealing) and 'Hard' (in the sense of direct, uncompromising, hard-hitting). However, as suggested by the epigraphs, rather than signifying distinct categories, these terms are attributed to a cluster of performance dynamics. After framing the aspects of complicity to be engaged with here, I will explore some of the salient features of these performance modalities as manifested in a cross-section of recent productions. This will prepare the ground for attempting to identify how some of the performances point to a post-TRC turn in South African theatre.

\section{Performative structures of address and 'the complexity of complicity'}

In his study Complicities: The Intellectual and Apartheid (2002), Mark Sanders claims that imaginative literature is useful as a vehicle for representing the complexity of complicity. This is because the act of invention enables ways of articulating complicity through finding a substitute 'in the literary, in the possibilities of alterity offered by its structures of address'

\section{https://repository.uwc.ac.za/}


(emphasis in original, 2002, p. 97). ${ }^{4}$ Sanders's claim can usefully be applied to performance, which offers rich scope for imaginatively realised 'structures of address'; moreover, as a public art form, performance can engage readers powerfully through employing diverse performance modalities.

According to Sanders, 'One's human-being is folded together with the other, the human-being of the other; and that other is the stranger' (p. 125). It is for this reason, claims Oliver, that we have an ethical responsibility to be self-critical in our responses to others:

We can never stop interrogating our notions of justice, democracy and freedom, which means we can never stop asking ourselves why we do what we do, why we value what we value, why we desire what we desire, why we fear what we fear' (2004, p. 85). ${ }^{5}$

These remarks speak to the aspects of complicity that are of interest here. Instead of the common focus on complicity in relation to culpability and private as well as collective guilt for apartheid crimes (as explored in TRC-inflected works), the emphasis here is on how complicity is explored in relation to what can be termed the 'alterity within,' and also a recognition of how 'our human-being is folded together with the other' (Sanders 2002, p. 125). To oversimplify a highly complex issue, my interest is in how performance can serve as a catalyst for recognising what Appiah calls 'commonality despite difference' (2006, p. xvii). Oliver's remarks on selfquestioning, including 'why we desire what we desire, why we fear what we fear,' are integral to the aspects of complicity that will be explored in relation to the three performance modalities identified here, and in particular, as applied to what will be described as Thick theatre.

There are marked distinctions in how complicities are staged. The first and most complex manifestation of complicity is produced when it is the audience who become aware of their own complicity as a result of experiencing what Sanders refers to as the shared 'foldedness of humanbeing' (2002, p. 9), which is made visible through the performance event. This is a consequence of the aesthetic engagement generated by performance, which enables a shift in audience perception. The re-cognition of complicity is described as an acknowledgement of (often tacit or unwilling) complicity in injustice (as suggested by the reference earlier to the 'frisson of white guilt'), and leads to an acknowledgement of 'responsibility-in-complicity.' This, acknowledgement, according to Sanders, is a necessary stage before one can grapple with, or 'resist' complicity. In other words, Sanders insists that before complicity can be resisted, it has to be recognised and acknowledged.

Secondly, complicity can feature as a subject explored in the play, where the audience 'witnesses' ${ }^{16}$ how characters reveal, or become aware of, their own or collective complicity, often through the unveiling of family secrets or as a result of introspection. On the other hand, some works explore what Sanders calls 'active complicity'; this entails collaboration in injustice, which then works itself through individual relationships over time. Finally, complicity is sometimes staged more confrontationally or explicitly so that audience members feel implicated in complicity. The focus on various aspects of complicity signals a grappling with, rather than reacting to, the post-apartheid condition in which discourses of exceptionalism and difference still dominate. After all, complicity does not only involve political and social injustice, but can include the stifling legacy of gendered, generational and embedded cultural bias as well. 
Before unpacking in more detail the way complicity is worked through in diverse theatre modalities, it is useful to situate the works to be discussed in relation to some of the dominant themes and performance trends that become evident during various annual theatre festivals in South Africa. For the purposes of this discussion I will focus on some of the works performed during the 2009 Grahamstown Festival to illustrate how the different theatre modalities co-exist and indirectly speak to one another. For instance, Corrigall notes that one of the most popular theatrical vehicles was 'turning public discourses inwards' (The Sunday Independent 2009b, p. 25). ${ }^{7}$ On the other hand, Adrienne Sichel identifies 'journeying into memory [as] one of the major themes,' and comments on how 'boundaries of who performed what, where, how and with whom, were blurred or gloriously redefined' (Tonight online). For Zane Henry, 'the interrogation of identity' was 'what resonated loudly.' Again, these are not new trends; they have been well documented since the early 1990s, which ushered in the rapid unsettling of the 'certain certainties' associated with the theatres of protest and resistance during the 1970s and 1980s (cf. Kruger 1999; Krueger 2007). ${ }^{9}$ Indeed, 15 years into democracy one can identify a healthy diversity of developments in local productions.

In exploring how aspects of complicity are staged it is necessary to select works that cut across different genres of performance. As noted above, these are loosely clustered here as Thick, Reflective and Hard performance modalities. The reason for drawing these (admittedly tenuous) distinctions is to argue that the complicities explored here are shaped by distinctive performance styles, which operate, in Sanders's terms, as 'forms of address.' In other words, the fictional and performative mode allows scope for addressing and speaking to, or for, those whose voices and experiences are not made public in other discourses. The performance modalities described here refer not simply to types of performance, but also to the kinds of responses generated. For this reason the focus will be on Thick theatre, which, as I shall show, provides the most challenging scope for exploring the staging of complicity, while examples of Reflective and Hard theatre provide useful points of comparison. The works to be discussed include Magnet Theatre's Every Year, Every Day I Am Walking (2006) and their Ingcwaba Lendoda Lise Cankwe Ndlela (The Grave of the Man is at the Side of the Road) (2009), Fred Khumalo's Touch My Blood (2009), Jonathan Nkala's The Crossing (2009) and Mike Van Graan's Iago's Last Dance (2010).

\section{Performance modalities: thick, reflective and hard}

I have adapted the term Thick theatre from the key concept of 'thick description' as employed by cultural anthropologist Glifford Geertz in his seminal chapter, 'Thick Description: Towards an Interpretive Theory of Culture' (1973). Geertz explains why he borrows the term 'thick description' (coined by Gilbert Ryle) to emphasize the interpretative function of 'reading' cultural events:

Believing, with Max Weber, that man is an animal suspended in webs of significance he himself has spun, I take culture to be those webs, and the analysis of it to be therefore not an experimental science in search of law but an interpretive one in 
search of meaning. It is explication I am after, construing social expressions on their surface enigmatical (1973, p. 5).

While Geertz is addressing approaches to ethnography, his emphasis on 'reading' cultural events can be re-contextualised and translated into refer to what I term Thick theatre. What is useful about his approach is the way it attempts to address 'social expressions on their surface enigmatical.' Furthermore, his comments on how 'Doing ethnography is like trying to read (in the sense of "construct a reading of') a manuscript' (1973, p. 10), is suggestive in terms of audience responses generated by Thick theatre modalities. Geertz refers to the 'manuscript' that is encountered by the ethnographer (or in this case the performance event), as, 'foreign, faded, full of ellipses, incoherencies, suspicious emendations, and tendentious commentaries, but written not in conventional graphs of sound but in transient examples of shaped behaviour' (1973, p. 10). In summary, for Geertz, 'thick description' refers to 'a layered, rich contextual description of an event that encourages the reader to get close to the meaning of those who experienced what the author is describing ... the reader gets the sense of "being there" (in Goldman-Segall 1994, p. 8). However, one remains aware that the story being told is an 'incomplete story,' where 'the reader fills in the blanks' (Goldmann-Segall 1994, p. 8).

Thick theatre here refers to theatre that is richly layered, attempts to give physical expression to unspoken and half-recognized experiences, draws on local histories and vernacular traditions, and often incorporates multimedia performance styles that unsettle surface realties and 'given' knowledge. In the process the spectator can become a co-author of meanings generated, and the relationship paradigms between those situated as host, or guest, or stranger, become blurred (see Derrida, $O f$ Hospitality 2003). At the same time, the term 'thick' in the sense of deep and difficult to access also refers to experimental theatre characterized by its search for a new language of artistic expression and for finding expression for the 'inner life' of the unconscious. As noted earlier by Kelly Oliver, this is integral to grappling with the 'complexity of complicity.'

In his description of the development of avant-garde or experimental theatre during the 1960s James Roose-Evans quotes painters like Franz Marc on the need to create a language that would 'break the mirror of life so we may look being in the face' (1989, p. 3), and Kandinsky, for whom 'the artist's eye should always be alert to the inner necessity.' For, '[i]n this way, and in this way alone, as Paul Klee observed, could the secretly perceived be made visible' (1989, p. 3). In other words, instead of holding the mirror up to nature as in naturalism, the mirror reflects 'the space within', that which is 'inexpressible,' yet also recognised. Indeed, one could say that it is the 'secretly perceived' that is recalled in the first epigraph when Creon, in Magnet Theatre's 1994 South African version of Medea, addresses Medea as 'stranger,' 'foreigner' and 'barbarian.' However, it is Creon's own 'other' self, his 'dark shadow' that he fears he will encounter when looking at Medea. (It is telling that this scene from a 1994 play already points to some of the underlying causes of the xenophobic violence that has recently surfaced so dramatically in the South African body politic.) The works from the 2009 Grahamstown Festival that can be read in terms of Thick theatre include Jay Pather's Bodies of evidence, ${ }^{10}$ and Magnet Theatre's Every Year, Every Day, I Am Walking and 
more especially, Ingcwaba lendoda lise cankwe ndlela (The Grave of the Man is at the Side of the Road), directed by Mandla Mbothwe, also of Magnet.

The second epigraph, by Sri Lankan writer Romesh Gunesekera, neatly captures a common concern for artists living through periods of dramatic political transition. Gunesekera's observation points to the necessary but uneasy dialectic that the artist feels constrained to maintain between present and past, remembering and forgetting. Reflective theatre attempts to balance past and future, learning and healing, and it both reflects upon and re-presents aspects of the post-apartheid condition from diverse (though often conventionally staged) perspectives. The term 'Reflective' thus points to reflecting on, or looking back onto the past, while at the same time not allowing the present and future to become over-determined by the past. Apart from this application (which is also how Hauptfleisch categorises the shift from 'theatre of anger' to 'theatre of reflection' in the later 1980 os (2007, p. 17), there is another sense in which ideas are reflected from actors to audience, not as in a mirror, but rather as a window onto post-apartheid experiences. In other words, unlike Thick theatre where the audience can become the co-author or the one who 'fills in the blanks,' in Reflective theatre the audience witnesses and empathises, but does not necessarily share in the responsibility-in-complicity that is explored. This is often a product of the script, which spells out issues too emphatically for anything but a passive, or at best empathetic, response. Moreover, a rather one-dimensional perspective is often produced by the naturalistic performance styles commonly employed in Reflective theatre. This performance modality is evident in works which range from Fred Khumalo's Touch My Blood (2009) and Fatima Dike's The Return (2009) to Jonathan Nkala's The Crossing (2009), an autobiographical tour de force which tells the story of Nkala's own illegal crossing from Zimbabwe to South Africa.

On the other hand, Hard theatre, as indicated by Mike Van Graan's comments in the third epigraph, refers to strongly issue-driven works which pose 'hard questions,' either to provoke response to topical concerns, or are refracted through comedy and satire, which are common modalities of Hard theatre. While there is substantial overlap between this and Reflective theatre, in Hard theatre the aim is to make the audience rethink its own positions, rather than reflect on the positions of characters. It has an unashamedly political intent, while still aiming to entertain as 'good theatre. ${ }^{11}$ In this type of work one of the intentions is to foreground the audience's re-cognition of their own complicity-not necessarily through the 'shared foldedness of human-being' of Thick theatre, where recognition comes by filling in gaps but rather by the debates aired on stage. An example here is Van Graan's Iago's Last Dance, directed by Lara Bye.

As indicated earlier, however, the modalities Thick, Reflective and Hard are not fixed categories, but refer to constellations of performance dynamics. One can thus read performances in terms of a continuum of modalities; ${ }^{12}$ for example, Magnet Theatre's Every Year, Every Day, I Am Walking incorporates features associated with both Reflective and Thick theatre. 


\section{Facing the stranger in the mirror}

The Cape Town-based Magnet Theatre Company, started by Mark Fleishman and Jennie Reznek in the 1990s, has produced a corpus of work that exemplifies a number of the features of Thick theatre as outlined above. From its inception the company has been associated with innovative attempts to give physical expression to often unspoken or unrecorded memories and experiences. This is in keeping with their involvement in community-based and collaborative projects, which draw on local histories and vernacular traditions in order to unsettle given knowledge systems. The company is renowned for its experimental approaches to finding new languages of artistic expression, and especially the deployment of physical imagery for meaningmaking. As suggested earlier, this provides fertile ground for experimenting with 'structures of address' and the 'complexity of complicity.'

When looking at how the complicity is staged, however, one should take into account not only aesthetic engagement, but also how the meanings of a particular work are shaped by contexts that are complicit with what is being performed (and this recalls Geertz comments earlier). For instance, at a benefit concert hosted in Cape Town in May 2008 for the African refugees displaced by xenophobic violence, the staging of complicity was exemplified in a scene from Every Year, Every Day, I Am Walking (which was also part of the 2009 Grahamstown Festival). First performed in Cameroon in 2006, ${ }^{13}$ the play is directed by Mark Fleishman, and features Jennie Reznek and Faniswa Yisa with music by Neo Muyanga. Like Magnet's Ingcwaba lendoda lise cankwe ndlela, this work deals with issues of migrancy, home, loss and belonging, and tracks the journey of a mother (Reznek) and her daughter (Yisa), who are forced to flee from a nameless francophone African country and eventually land up in Cape Town after anonymous attackers set fire to their house. The actors, well known for their skill in speaking through movement, shift seamlessly between roles, languages and bodies, suggestive of the necessary fluidity of migrant identities unfixed from home and across time and space. The scene performed for the benefit concert was not a new work created for the event, but produced a fresh 'seeing' for those already familiar with the production. For instance, in an eerily somnambulistic moment, the audience (as in Reflective theatre) indirectly bears witness to the torching of the family house by vigilantes in the unidentified homeland when a childlike drawing of a house is set on fire. As acrid fumes slid into the overflowing auditorium of generally well-meaning middle-class patrons, eager to show support for the refugees in their midst, the scene appeared both strangely 'new' in this context, but also sickeningly familiar. Instead of being an enactment of the generic ethnic civil war in other parts of Africa or elsewhere, which is how the scene had previously been interpreted by most (the performers speak a French-inflected language in this section of the play), the same scene now bore witness to a shameful period in our own local history during the 1980s, when vigilante witdoeke (white bandanas) rampaged through the informal settlements around Cape Town in orchestrated but apparently random acts of violence. Or, when victims of the fatal 'necklace,' isolated by the deathly ring of fire, haunted the daily news as communities turned their rage inward on those labelled impimi or informers. Even more chillingly, the scene evoked the then still fresh image of a burning man from Mozambique who was set alight in a Johannesburg township during the 
xenophobic rampage in March 2008, and who came to epitomise the trauma of these events. ${ }^{14}$ Following these attacks the media initially focused on a sense of collective complicity, as typified in the claim made by Hein Marais: 'these outrages call us all to account' $(2008$, p. 5). His next comment uncannily recalls Creon's address to Medea in the first epigraph: 'Like staring into a shattered mirror, we might not immediately recognize ourselves or approve of the images aimed at us. But that's us staring back at us' (Marais 2008).

Another scene from the play that in retrospect seemed prophetic is when mother and child arrive in Cape Town and encounter familiar comic caricatures such an arrogant but fearful white English-speaking madam, a xenophobic Xhosa woman fruit-seller, and an indifferently officious Home Affairs clerk (all played by Reznek). As an attempt at integration the refugee child (Yisa) learns to name parts of her body in English, but as she laboriously identifies each aspect of herself in the new language, her personal fragmentation in the service of the foreign naming becomes demonstrated through the accompaniment of other children's hissed finger-jabbing taunts, makwere, makwere, which punctuate each newly learnt word, overriding her attempts to re-name herself in order to be accommodated in the socalled Mother City. This again is in keeping with Marais' 'reading' of the violence meted out to foreign fellow-Africans: 'like it or not, this seethe of gory frustration and opportunism also involves statements of affirmation about who belongs, what identities constitute that status and who has legitimate claims to the state' (2008). It is significant that both in his analogy of the mirror image, as well as here, he prefaces his remarks by saying 'like it or not,' suggesting that these are uncomfortable truths because of having to accept what Sanders terms 'responsibility-incomplicity.'

A good example of how Thick theatre unsettles surface realities is Ingcwaba lendoda lise cankwe ndlela (The Grave of the Man is at the Side of the Road), directed by Mandla Mbothwe of Magnet Theatre. This work is performed in isiXhosa with English subtitles and explores the trauma of families separated through the system of migrant labour. While this system was legislated during the apartheid Bantustan era, it has continued, unlegislated, into the present as a result of the on-going impoverishment of rural communities who seek employment in urban areas. Mbothwe's decision to use isiXhosa is informed by his concern with revitalising connectedness to vernacular experiences and traditions (rather than simply re- representing these as 'packaged' traditions). One could say that the work attempts to articulate the 'other side of the story' of the migrant worker from inside his or her homeland by focusing on the unspoken psychic trauma (or 'inner realities') resulting from this displacement within the South African homeland, which affects not only the migrant, but those left behind.

Throughout, the stage is haunted by the ghostly image of a road projected onto a screen, signalling the on-going trek along the N2 from the Eastern Cape to Cape Town. The awkwardto-decipher English translation, which is superimposed at intervals on the screened road in motion, is both strongly metaphoric and enigmatic, recalling the 'foreign,' 'faded' and 'elliptical' manuscript referred to by Geertz earlier. The pull between community cohesion and its splitting through the experience of migrancy is staged using visual and physical images which repeatedly coalesce and then break apart. In this way pain and longing become palpable, and literally and figuratively stretch across the stage and over time and distance. When the father cuts the symbolic thread signifying his connection to home, its traumatic severing is felt rippling through those 
tied to him who remain. In this way the audience is drawn into a psychic landscape where bodies and voices speak as one and many. The audience is made aware that the translated words superimposed on the screen are a mere proxy for the depth of the half-grasped 'inner life' that lurks beneath what is seen and heard; at the same time the 'ellipses and gaps in understanding' are countered by the vocally compelling performance by Faniswa Yisa as waiting, grieving and outraged wife-mother who is abandoned by both her husband and later her daughter who goes in search of her father. One example of how the embodied inner life is made visible is in the repeated sudden flurry of quick slaps on one ear first by the father separated from his daughter, and mimicked by her, and then echoed in her frantic knockings on closed doors in search of him. While we do not necessarily 'understand' each gesture and action, nor the incantatory traditional Xhosa (which even urban-based mother-tongue speakers find obscure at times), the audience is made to see and hear the memory, and as it were to listen the voice in the head, the call that wants to be heard more clearly but also perhaps kept at bay, as suggested by the hand slapping at the sideways-tilted head.

This is a good example of how Thick theatre engages the audience in making meaning, and one could draw parallels here with what Toni Morrison has described as 'participatory reading.' Morrison claims:

My language has to have holes and spaces so the reader can come into it. He or she can see something visceral, see something striking. Then we (you, the reader, and I the author) come together to make this book, to feel this experience $(1983$, p. 125).

There are synergies here with Geertz's call for a layered, rich contextual description which "encourages the reader to get close to ... the sense of "being there" (in GoldmanSegall, 1994, p. 8). However, as Morrison reminds us, one is aware that the story being told is an 'incomplete story,' where 'the reader fills in the blanks' (GoldmannSeagall 1994, p. 8). In Ingcwaba lendoda lise cankwe ndlela the structures of address employed foreground an awareness of the foldedness of human-being, even if by virtue of recognition of one's own 'difference' from the specific experience being presented. This results in an aesthetic distancing which precludes simply sentimental or easy empathy with the experiences of others. By contrast, in Reflective theatre these blanks are often filled in for the audience, as demonstrated by Fred Khumalo's Touch My Blood, based on his novel of same title.

\section{Reflective theatre: forgetting and healing, or remembering and learning?}

Fred Khumalo's Touch My Blood was transposed for the stage by James Ngcobo, with Bheki Mkwane as the young Fred. It explores Khumalo's own coming of age as a writer. The play moves between present and past in exploring the choices Khumalo had to face in choosing his writing before active involvement in challenging apartheid oppression. As common to such situations, feelings of guilt often mask a sense of unwilling complicity in injustice. However, instead of achieving a Brechtian distancing effect to deepen understanding of social and political forces and how they shape individual lives, the awkward insertion of the older Fred as editorial voice that interprets events produces a certain flatness in this production. This is because 
the heavy-handed authorial voice dissipates the tension between reflecting upon and revealing, and does not provide 'gaps' for the spectator to engage with. Another contributing factor is the attempt to be 'true' to the novel, which does not translate well to stage as a result. On the other hand, an example of Reflective theatre which articulates the complexity of complicity effectively is Jonathan Nkala's autobiographical play, The Crossing (2009), directed by Bo Petersen. What happens here is that the audience is seduced by Nkala's charismatic performance to laugh with and at him as he enacts the grotesque yet comic spectacle of violence and crass bigotry encountered by Zimbabwean refugees like himself only to realise, uneasily, that in the process we have become voyeuristically complicit in the very injustices and abuses he is subjected to by proxy, as well as recognising the pervasive ordinariness of xenophobic abuse dished out to foreigners in South Africa. In this case it is the very banal ordinariness of these abuses that result in recognition of complicity. At the same time, as suggested by the title, The Crossing also offers the possibility of transformation in that Nkala (as Khumbu), the 'illegal alien,' the 'stranger,' becomes the 'host' as performer, and we, the spectators, become 'guests' of his telling.

\section{Hard theatre, hard questions}

As suggested earlier, Hard theatre poses (often rhetorical) questions about complicity in various forms of social injustice. This approach is intended to raise awareness or at the very least to make the audience uncomfortable. One example of the effects generated by satiric 'unsettlement' is Mike van Graan's Iago's Last Dance. The work consists of three playlets based on the classic tales of Medea, Othello and Spartacus, which are linked by a common focus on betrayal and vengeance. In each case the same three actors explore the effects of HIV/AIDS on individuals and their relationships with those around them. As Van Graan points out in an interview, the HIV/AIDS pandemic has not been given the kind of attention in 'mainstream theatre' it deserves, and he expresses surprise that there is not a greater call for a 'theatre of outrage,' if not protest, given the scope of the AIDS genocide. This, he claims, is probably more socially devastating, in terms of the number of people who die each day, than apartheid. ${ }^{15}$ All three playlets have shocking twists, and the one that tackles the issue of complicity most directly is the last one, Vuyo's vegeance. Vuyo, a former freedom fighter is on trial for attempting to infect representatives of the state (Thabo Mbeki and Manto Tshabalala-Mtsimang) with his own HIV- positive blood as a protest against their AIDS denialism. His attack is foiled by a former apartheid operative now in State Intelligence with whom Vuyo has a shared history. The events are set in a courtroom where Vuyo the ex-soldier (Mbulelo Grootboom), his former and current betrayer (Jan-Henrik Opperman), and the State Prosecutor (Ntombi Makhutshi), face the audience, which then becomes a jury of sorts. Throughout, each character inhabits a strongly argued position, claiming to be only 'doing their job'; however, in the process the web of complicities each has to manage in the service of the 'job' becomes clear. A bleak picture emerges as Vuyo and his betrayer seem still trapped in the 'roles' they have felt assigned to them by the previous dispensation. Typically, it is the young black woman who literally 'gets it in the neck' when Vuyo stabs her (as a substitute for the absent 'official' targets of his rage) in a last desperate act of defiance. From being situated as the jury listening to the 
evidence presented by each character, the audience at the end find themselves in the position of being in the dock, as the accused, for their complicity with the state denialism on HIV/AIDS. At times (as with Iago's Last Dance), Hard theatre manages to escape the bind of over-determined didacticism by innovative staging; however, more often than not it results in work that does not go beyond staging positions framed as questions. At best it poses the hard questions in a way that offers scope for rethinking or gaining new insights, rather than rehearsing the new 'certain certainties' about crime, HIV/AIDS, xenophobia, and all that this entails in terms of the new apartheid which separates the poor from the rest of the citizenry.

\section{Towards a post-TRC turn?}

As argued here, the staging of complicity is shaped by the types of aesthetic engagement employed, from Hard theatre which implicates audiences in complicity, to Reflective theatre where complicity is explored in terms of the staged experience which is witnessed by the audience. However, the most challenging exploration of the complexity of complicity is achieved by the type of Thick theatre produced by, for instance, Magnet Theatre and practitioners like Jay Pather, Brett Bailey, Lara FootNewton, Marthinus Basson and others who have developed a strong reputation for producing textured work using physical images, generating multiple meanings through innovative stage metaphors which challenge common assumptions. These productions are often collaborative, involving research into local communities, and the question hegemonic knowledge, its production and dissemination. In the process these works often draw on history in order to play with contemporary realities.

When audiences are willing to 'fill in the blanks' and to risk becoming participants in making meaning as a response to the performative structures of address employed, an awareness of what Sanders refers to as 'responsibility in complicity' is made possible. Such responses are enabled by performance devices that have come to characterise a significant body of South African theatre, simultaneously distancing and engaging, drawing the audience into a distinctive push-pull aesthetic. As noted earlier, the recognition of responsibility in complicity is a necessary first step for resisting social injustice (Sanders 2002). It could thus be argued that the shift beyond personal and collective culpability and guilt for past injustices heralds a post-TRC turn by virtue of a deeper recognition of complicity.

This can provide the basis of an ethical self-interrogation, as outlined by Kelly Oliver, which is not just backward-looking but also future-directed. As Sanders claims, this requires recognising difference as a prerequisite for acknowledging that 'one's human-being is folded together with ... the stranger' (Sanders 2002, p. 125). However, this does not entail a simple or merely sentimental empathy with the experiences or inner lives of others. Instead, as Dominick LaCapra puts it, the spectator who is positioned as 'attentive secondary witness' to the experiences of others should experience an 'empathetic unsettlement' (1999, p. 696). In other words, empathy is qualified or limited by an awareness of one's difference from the other whose experiences we are witnessing. As we have seen, in Magnet Theatre's South African version of Medea, Creon commands Medea to 'Look away' so that he may not 
see himself reflected in her. However, it is in Thick performance modalities such as employed here that our complicit 'foldedness of human-being' is made visible through aesthetic distancing. This happens through the push-pull aesthetic referred to above and suggests an invitation to the stranger. After all, it is in performance that hosts can become guests or even strangers; moreover, strangers can become hosts who welcome other strangers.

\section{Acknowledgements}

Warm thanks to Marcia Blumberg of York University for providing helpful feedback on an earlier draft of this article. 


\section{Notes}

1. Following the initial eulogies after its release here, there has been a strong wave of protest about the racist stereotypes that are replicated in the film. In his entertaining and erudite blog, Andries du Toit (2009) does not initially do justice to the issues raised by the representations of 'super evil' Nigerians. However, in subsequent discussions, he notes that the problem with the film is that in playing with caricatures they are not sufficiently ironised. See also Lee (2009).

2. In an interview with Jessica Blasé (2009), Bailey describes his work as performance art- cum-promenade theatre where spectators move between sites: 'expect to journey into the dark part of our society.'

3. See Zane (2009) 'The Interrogation of Identity.

4. For further discussion of Sanders and Oliver in relation to South African cultural production, see Flockemann (2010).

5. Oliver distinguishes between two kinds of 'witnessing' that are also bound up with the distinction between one's subject position (as 'eye-witness') and one's subjectivity (as 'bearing witness'): 'there is tension inherent in the notion of witnessing in the sense of eye- witness to historical facts or accuracy' and 'witnessing in the sense of bearing witness to a truth about humanity and suffering that transcends these facts.' Testimony, on the other hand, 'is usually a spoken or written account of something seen or experienced' (2004, p. 81). I thus use inverted commas to describe the kind of provisional 'witness' position that the audience occupies. (Thanks to Brian Harper for alerting me to these distinctions made by Oliver.)

6. Oliver adds, 'Yet without engaging the unconscious our self-interrogation will never be vigilant enough. Only by postulating the existence of the unconscious will we be humble enough to question our own motives, fears and desires' (2004, p. 85); this has some bearing on the kinds of 'structures of address' explored in performance to give expression to an 'inner reality.'

7. Corrigall claims that looking at works in relation to one another serves as a 'complex puzzle that, when slotted in, offer a comprehensive picture of life in South Africa' (2009a), p. 25).

8. Henry lists 'Racial identity, Sexual identity, Social identity, Political identity. Who they are and how the hell they fit into a new South Africa with new definitions of old terms' (2009).

9. Hauptfleisch (2007) provides a comprehensive overview of major trends in South African theatre from the pre-colonial era to 2003. See also Kruger (1999) and Krueger's (2007) discussion of theatre as vehicle for performing transformations of identity.

10. Jay Pather's Bodies of Evidence (2009) is a powerfully visceral and ambitious work that attempts to express the inexpressible, and confronts the audience with the disjunctures between given or official knowledge and embodied experience. As such the work exemplifies the call for acknowledgement of the inner life, the 'secretly perceived' referred to by Paul Klee earlier.

11. In an interview with students at UWC Van Graan claimed that the relationship between the personal and the political is no less relevant now than under apartheid. Moreover, he said that 'we now have greater skill, experience and resources, which 
should mean that we should be able to explore socially relevant issues and still make good theatre' (Unpublished interview 2009, UWC).

12. See Hauptfleisch's (1997) discussion of this continuum.

13. Every Year, Every Day, I Am Walking was commissioned by the African Festival for Children and Youth Theatre in Yaounde, Cameroon and was influenced by creative workshops run by Judith Rudakoff of York University, and inspired by The Suitcase Stories, produced as part of a therapy process with refugee children in Johannesburg. It is described by Magnet's press release as 'a piece about dislocation, about what home means. It explores what it means to lose the safety and security of home as a result of wars.'

14. The media ran a picture dubbed 'The Man in Flames' depicting an immigrant from Mozambique set alight during the xenophobic violence in Johannesburg in 2008. His name was Ernesto Alfabeto Nhamuave. The picture was used to publicise the brutality of the attacks; see 'The Man in Flames' by Bhekimpilo Sibanda (2009). 15. Unpublished interview 2009, UWC. 


\section{References}

Appiah, A., 2006. Cosmopolitanism: Ethics in a world of strangers. London: Penguin.

Blasé, J., 2009. Bailey explores Grahamstown faultline. Cue online 10 July. http://cur.ru.ac.za/ theatre/drama/2009/html.

Corrigall, M., 2009a. The aliens have landed. The Sunday Independent, 20 September, 25. Corrigall, M., 2009b. Looking inwards. The Sunday Independent, 23 August, 25.

Derrida, J., 2003. Of hospitality (trans. R. Bowlby). Stanford, CA: Stanford University Press. Dike, F., 2009. The return. Cape Town: Junktets.

Du Toit, A., 2009. Blog: Loving the alien: Apartheid, racism \& District 9. http://asubtleknife. wordpress.com/2009/09/04/science-fiction-in-theghetto-loving-the-alien.

Fleishman, M., 1994. Medea. Unpublished manuscript.

Flockemann, M., 2010. Little perpetrators, witness bearers and the brave and restless: Towards a post-transitional aesthetics'. English Studies in South Africa, 53 (1), 21-34.

Geertz, C., 1973. The interpretation of cultures. New York: Basic Books.

Goldman-Segall, R., 1994. Whose story is it anyway? An ethnographic answer. IEEE Multimedia, 1 (4), 7-12.

Hauptfleisch, T., 1997. Theatre and society in South Africa: Reflections in a fractured mirror. Pretoria: J.L. van Schaik.

Hauptfleisch, T., 2007. The shaping of South African theatre: An overview of major trends. In:

A. Arndt and K. Berndt, ed. Words and worlds. African writing, literature and society. Trenton, NJ: Africa World Press. Available from:

http:74.125.95.1323/search?q=cache:AQe4uua01BwJ:academic.sun.ac.za/dra ma/Afri... [Accessed 20 July 2009].

Henry, Z., 2009. The interrogation of identity. Tonight, 14 July. http://www.tonight.co.za/index.php?fSectionld=3860\&farticleld $=5080888$.

Hussein, A., 2002. Romesh Gunesekera: After an odyssey, paradise regained. The Independent, UK. http://www.independent.co.uk/artsentertainment/books/features/romesh-gunesekera-after-an-odyssey-par...9.

Khumalo, F., 2009. Touch my blood. Unpublished performance.

Krueger, A., 2007. Performing transformations of identity: Ethnic nationalisms and syncretic theatre in post-apartheid South Africa. English Academy Review, 24 (1), 51-60.

Kruger, L., 1999. The drama of South Africa: Plays, pageants and publics since 1910. London: Routledge.

LaCapra, D., 1999. Trauma, absence, loss. Critical Inquiry, 25 (4), 696-727. Lee, C., 2009. The first alien apartheid film. Cape Times Friday, 28 August, 3.

Magnet Theatre. 2006. Every year, every day, I am walking. Directed by Mark Fleishman. Unpublished playscript.

Marais, H., 2008. The foreigner in the mirror. Mail \& Guardian 23-29 May http://www.mg.co.za/articledirect.aspx?articleid=339989\&area=\%2finsight\%2 finsightcomment_and_analysis\%2f.

Mbothwe, M., 2009. Ingcwaba lendoda lise cankwe ndlela. (The grave of the man is at the side of the road). Unpublished playscript. 
Morrison, T., 1983. In: C. Tate, ed. Black women writers: A work. New York: Continuum Publishing Company, 117-31.

Nkala, J.K., 2009. The crossing and the bicycle thief. Cape Town: Junkets Publisher. Oliver, K., 2004. Witnessing and testimony. Parallax, 10 (1), 79-88.

Pather, J., 2009. Bodies of evidence. Unpublished performance.

Roose-Evans, J., 1989. Experimental theatre: From Stanislavsky to Peter Brook. London and New York: Routledge.

Sanders, M., 2002. Complicities: The intellectual and apartheid. Durham, NC and London: Duke University Press.

Sibanda, B., 2009. The man in flames. Critical Arts, 23 (1), 116-20. Van Graan, M., 2010. Iago's last dance. Cape Town: Junkets.

Van Graan, M., 2009a. The art of democracy. Cape Times, 9 March, 9.

Van Graan, M., 2009b. Unpublished interview. University of the Western Cape, August 2009. 